\title{
Essais
}

Revue interdisciplinaire d'Humanités

Hors-série 1 | 2013

L'estrangement

\section{L'inquiétante familiarité ou comment tenir les anciens Grecs à distance}

\section{Christophe Pébarthe}

\section{(2) OpenEdition}

1 Journals

Édition électronique

URL : http://journals.openedition.org/essais/2282

DOI : 10.4000/essais.2282

ISSN : 2276-0970

Éditeur

École doctorale Montaigne Humanités

\section{Édition imprimée}

Date de publication : 15 octobre 2013

Pagination : 107-128

ISBN : 978-2-9544269-7-4

ISSN : 2417-4211

\section{Référence électronique}

Christophe Pébarthe, «L'inquiétante familiarité ou comment tenir les anciens Grecs à distance », Essais [En ligne], Hors-série 1 | 2013, mis en ligne le 05 octobre 2020, consulté le 12 octobre 2020 URL : http://journals.openedition.org/essais/2282 ; DOI : https://doi.org/10.4000/essais.2282 


\section{L'inquiétante familiarité ou comment tenir les anciens Grecs à distance}

\section{Christophe Pébarthe}

Dans un ouvrage paru en 2000, Les Grecs, les historiens, la démocratie, cherchant à établir l'existence d'une Grèce à la française, Pierre Vidal-Naquet qualifiait la relation que les historiens entretiennent avec le monde grec ancien d'" inquiétante familiarité »'. Il faisait allusion de façon explicite à l'article publié en 1919 par Sigmund Freud, Das Unheimliche 2 . Forgé à partir de Heim, la maison et du préfixe privatif, un, ce terme ne se traduit pas aisément en français. Si la proposition de Marie Bonaparte est le plus souvent retenue, "l'inquiétante étrangeté ", d'autres, faisant remarquer que cette traduction laissait de côté la maison, la familiarité et faisait disparaître la négation, ont proposé "l'étrange familier " (François Roustang). D'autres traductions seraient possibles, par exemple "le non-familier ». La difficulté n'est du reste pas propre au français puisque Freud lui-même éprouve le besoin de consacrer la première partie de sa réflexion à l'établissement d'une définition qu'il énonce ainsi. "L'inquiétante étrangeté est cette variété particulière de l'effrayant qui remonte au depuis longtemps connu, depuis longtemps familier ". Il s'agit donc de comprendre comment ce qui est familier "peut devenir étrangement inquiétant, effrayant $»^{3}$. Il faut au préalable évacuer la piste étymologique. Unheimlich est l'antonyme de heimlich, (du pays) et de vertraut (familier). Le non familier ne saurait être associé de façon systématique à l'effrayant, ni même à l'inquiétant. Citant un dictionnaire de 1860, il trouve une citation dans laquelle les deux termes sont associés, à propos d'une famille : "C'est ce que nous appelons unheimlich ; vous, vous l'appe-

1 Pierre Vidal-Naquet, Les Grecs, les historiens, la démocratie. Le grand écart, Paris, La Découverte, 2000, p. 22.

2 Pour une traduction française récente, on se reportera à celle de Bertrand Féron [Sigmund Freud, "L'inquiétante étrangeté ", in id., L'inquiétante étrangeté et autres essais, Paris, Gallimard, coll. Folio, (1919 pour l'édition originale), p. 213-263. (1985)] qui, faute de mieux, a conservé le titre français donné par Marie Bonaparte.

3 Sigmund Freud, op. cit., p. 215. 